\title{
Crisis of Identity and Mimicry in Orwell's Burmese Days Seen through a Local Native Character U Po Kyin: A Postcolonial Reading
}

\author{
B. Endo Gauh Perdana \& Elisa Dwi Wardani \\ endo.gp07@gmail.com \& elisa@usd.ac.id \\ English Letters Department, Universitas Sanata Dharma
}

\begin{abstract}
This study analyzes how crisis of identity and mimicry occurs in the postcolonial discourse. A local native character whose name is U Po Kyin is the focus of the study. As a native character, he holds a high ranking position for local in the British Raj in Burma. However, he is portrayed as a corrupt official as he accepts bribes and denounces his rival. His ambition to get the membership, an elite European Club, drives him infuriated to destroy his rival's reputation because naturally it is him who would be elected as the first local member of the Club. At the end of the novel, Kyin finally secures his membership but he fails to atone his evil-doings by building pagodas as a Buddhist. Kyin's attitude is seen as how he manages to deal with his inferiority towards the British. He is also observed to mimic the British as his strategy to erase the idea of being colonized.

There are two problem formulations in this study. The first is to find out how $U$ Po Kyin suffers from crisis of identity through his characterization in the novel. Then, the second objective is to understand how his crisis of identity leads him to mimic the British.

This study condludes that $U$ Po Kyin suffers from crisis of identity. He is oppressed conscious and unconsciously by the British. This causes his self-image to be eroded. Even though he is relatively wealthier than his fellow natives, he still craves for more as he realizes that there is something more than money. He wants to be detached from his inferiority. The elite European Club represents his ambition because it offers him status to be like the British. That is why he schemes to crush his rival. In his schemes, denigrating his rival means to mimic the British because he needs to differ himself from the natives. However, he is still powerless because the British still consider him as the subject of colonialization.
\end{abstract}

Keywords: crisis of identity, mimicry, postcolonial reading

\section{Introduction}

The writer chooses George Orwell's Burmese Days to study because it represents the situations of South East Asian nations as most of them were colonized. Colonized nations share certain characteristics in common as proposed by Loomba "Colonialism ... reshapes, often violently, physical territories, social terrains as well as human identities" (Loomba, 2005:155). In Southeast Asia, there were at least three colonial nations that gained control over nations in the region and made them into their colonies (Wiharyanto, 2005:113). They were British that ruled in Malaysia, Singapore and Myanmar, French that ruled in Vietnam, Laos and Cambodia, Spanish ruled in the Philippines and Dutch ruled in Indonesia. Upon a series of agreement between the colonials, Thailand was left free politically but controlled economically. Thus, almost all countries in Southeast Asia were colonized. It is presupposed that they share 
the same spirit to be free from imperialism. The novel is also believed to depict a complete situation where the colonial regime oppressed the native.

Another reason why the writer chooses Orwell's piece to study is because he is known as a writer, essayist as well as journalist who explicitly addresses and expresses his political issues in his work s. In his opus magnum, 1984 and Animal Farm, Orwell criticizes satirically a totalitarian government and its instruments. Homage to Catalonia was written after he had taken part in Spanish Civil War (Lee, 1969:819). These show that his life experiences apparently influenced his works in many ways. Hence, he even utilized those experiences as backgrounds and argumentations for him to write a literary work including Burmese Days.

Orwell was a police officer in Burma who later resigned from Indian Police (British Police force stationed in British Raj in India and Burma) in 1928(Rai, 1983:49). This can be seen as a sign of his rejection of imperialism. He wrote Burmese Days afterwards but worried upon the publication, as it would disrupt British Office in India (Rai, 1983:49). He proclaimed himself as the one who concerned about Burmese people as he stated in one of his essays, Shooting an Elephant "Theoretically and secretly, of course - I was all for the Burmese and all against their oppressors, the British" (Orwell, 1936). Years after that, he finally published the novel in 1942. Orwell's attitude implies on one of his characters in the novel, John Flory who spends most of his time in the colonized country, Burma. Flory is pictured as the friendliest and loved by the native as he respects their culture and traditions. This can be taken as representation of Orwell's personal statement towards British imperialism in Burma which was unlike most of his colleagues.

The focus of this study is the identity issue. The image of self that is destroyed because of colonialization is a sign of cultural denigration. Therefore, the colonized people see themselves as inferior than the colonizer. This can be seen from the native characters who pursue their dreams to be 'united' or as if having close relationship with one of the Europeans (Orwell, 1950:15). The locals are longing for identity that would establish their status in the community as portrayed by U Po Kyin, a local magistrate who devises a plan to be the first local member in an expatriate community by all means. The pursuit of being West, the British imperialism which most the Orient, those who were colonized, aim to have, according Bhabha, is "a dream of the deprived, the illusion of the powerless" (Bhabha, 2004: xi).

\section{Identity Crisis}

Rutherford provides an example where he uses the story of Lawrence of Arabia as the background. He proposes the idea that when Lawrence was stranded in the dessert, he faced the confusion of himself. Dessert was metaphorically used as the border between the known and unknown territories as Rutherford puts it "margin between the habitable and the inhabitable" (Rutherford, 1990:9). Then, Lawrence suffers from crisis of identity as stated by Rutherford:

For Lawrence the dessert left him neither Arab nor English: 'I had dropped one form and not taken on another'. In a more contemporary setting Baudrillard has commented, 'in the dessert one loses one's identity' (Rutherford, 1990:10).

Then, the dessert is assumed to the sign of difference as a line to separate one to the other. The idea of the dichotomy of "white/black, masculine/feminine, hetero/ homosexual, where one term is always dominant and the other is subordinate, that our identities are formed" applies in the representation of the desert as a border (Rutherford, 1990:10).

According to Rutherford, there must be an interrelationship between one identity (society) with another where power embodied as an important aspect. This means that the relationship between identity 
to another identity is based on assumption of power and authority. Rutherford discusses the failure of categorization of the Communist Party to promote the erasure of the oppression of sexuality, race and gender. The system successfully recognizes the power every dichotomy of sexuality, race and gender but it fails to eliminate "the element of practical politics: choice, doubt, strategy, planning, error and transformation" (Rutherford, 1990:17). As a result, the form of oppression exists because everyone falls into polarities like white-black, working class-ruling class and no exception of colonial and colonized. Then, the colonial government happens to claim to be superior as they believe they possess more power than the 'Other'. They commence to initiate the oppression against the inferior, the local natives.

Ashcroft offers the term 'Place and Displacement' to elaborate the crisis of identity in the postcolonial discourse. He insists that it is when the special postcolonial crisis of identity comes into being; the concern with the development or recovery of an effective identifying relationship between self and place (Ashcroft, 2002:8)

Thus, it is important to notice the relationship between the image of postcolonial subject, the colonized in certain aspect of location. Location here means how he is positioned in social structure of colonial life.

One of the main causes this phenomenon to happen is cultural denigration. Ashcroft indicates that there is always be a form of oppression. He explains that:

$A$ valid and active sense of self may have been eroded by dislocation, ... it may have been destroyed by cultural denigration, the conscious and unconscious oppression of the indigenous personality and culture by a supposedly superior racial or cultural model (Ashcroft, 2002:9).
The oppression exists because there is a claim from the 'supposedly superior racial' over the inferior. This practice destroys the self-image of the indigenous people. Though, sometimes, the devastation is highly manipulated in form of their slogan of enlightening people and support for the longevity of colonial prosperity.

The result of displacement is alienation (Ashcroft, 2002:9). As the image of self is eroded or destroyed, the crisis of self-image starts to appear. Ashcroft provides some results of displacement.

the possession and practice of 'Englishness', also show clear signs of alienation even within the first generation of settlement, and manifest a tendency to seek an alternative, differentiated identity? (Ashcroft, 2002:9)

It is when the colonized begin to be alienated among their native society. It is also clear to observe that those who tend to get acquainted of the Englishness suffer from crisis of identity.

\section{Mimicry}

As it has been introduced in the realm of literary devices by the famous Plato's term mimesis, mimicry here would occupy the same qualities. Bhabha explains that mimicry in postcolonial is "the desire for a reformed, recognizable Other, as a subject of difference that is almost the same but not quite" (Bhabha, 2004:122). It refers to the determination of the Other to signify themselves as the colonizer. They may acquire certain qualities but they will never be 'them'. Bhabha formulates that:

Mimicry is, thus the sign of a double articulation; a complex strategy of reform, regulation, and discipline, which 'appropriates' the Other as it visualizes power (Bhabha, 2004: 123)

However, mimicry also affects both sides, colonized and colonizer. The ambivalence of mimicry lies on the 'partial' 
part of the colonial subject. Colonizer is dependent upon the relation between the authoritative power of colonialism and the success of implying the power to the Other, the indigenous people. Partiality is seen from the position of mimicry as a strategic plan as well as menace (Bhabha, 2004: 123). This means that when mimicry is employed into practices there would be some menace effect which would disturb the stability of the colonial government. For example, when the British introduced proper education to certain class of people in India, the British were afraid that the intellectuals they produce would one day turn against them. Therefore, the colonized people are affected in a way that there is a group of local people who are enlightened as they receive the British education as well as they mimic the culture of the British. On the other hand, the British as the colonizer are not affected culturally. They would never consider the colonized as equal even though some of them are educated like them but still the British would be less concerned with the idea of equality. The British would consider more about how their empire is endangered as now there were some local intellectuals who were ready to criticize the British.

Bhabha also comments on the mimicry as a means of repetition rather than representation because the colonizer is put in the discourse of the failure of the colonial system itself. He said " ... the effect of flawed colonial mimesis, in which to be Anglicized is emphatically not to be English" (Bhabha, 2004: 125). Therefore, it is justified that colonized repeatedly practice the signification of colonial as if they (the Other) utilize the practice the power of being colonial or imperial. The identity associated with the English values as they have been dreaming of would never be achieved because they are only given selected knowledge and false and also limited authority under strict control of the British.

Rutherford has also remarked that identity is determined based on the politics of different. He agreed with Gramsci upon the idea of collective identity. Gramsci believed that politics is the new of the formation of new collective identity as shown in the strike of minority's leftist such as gay and lesbian groups. These groups are obvious fall into, if categorization is applied, left movements along with communist and feminist and other leftist. However, the strike triggers the revolutionary politics of culture resulting that "... the politically negotiable and incomplete character of identity and social formations" (Rutherford, 1990:19). Thus, identification of political identity as in colonial system where oppression was severe and attached to the system of colonial itself is never be nor singular neither predictable.

The ambivalence of mimicry appears because identity cannot be reduced into single concept because "identity marks the conjuncture of our past with the social, cultural and economic relations we live within." (Rutherford, 1990:19). This means that an identity someone or society claim to be is consist of many layers which emphasized on the past and its relation to the present. This concept also argues any forms of fixity and essentialism because "social, political and class formation do not exist a priori, they are a product of articulation" (Rutherford, 1990: 20). As a result, there is no point when everything (class, gender, and race) just happen without any correlation with the past events.

What drives someone who is already attached to one identity move to another identity is human intention itself. Human intention as in form of wish cannot be separated from the past events. According to Freud as quoted by Rutherford; "You will see from such an example how the wish employs some event in the present to plan a future on the pattern of the past." (Rutherford, 1990:21). This recognizes any events that happened in the past as determining factors to produce wishes. In the postcolonial discourse, the wish to get out of a society or identity can be seen from the oppression so that someone would wish to be oppressed no more by trying to be like the oppressor.

\section{Burma Under British Imperialism}


British annexed Burma in 1885 when they captured the royal capital of last Burma kingdom, Mandalay. Then, British exiled King Thibaw and Queen Supalayat to India where the couple spent rest of their lives. The palace which was located in Mandalay, were turned into military based. It became the center of colonial life equipped with luxury facilities such as a polo field, a golf course and tennis courts and also a chapel found within the complex of the palace since the British took it under control (Larkin, 2004:29).

British also had redecorated many rooms in the palace. They placed a billiard table in one of sacred rooms that was used to pay homage for Queen Supalayat. This provides a picturesque description about the typical interior of the Club in Burmese Days. The Club refers to the elite club, whose members are all European, where they spent most their times gathering together to enjoy home-like atmosphere by drinking gin or playing bridge and else. The Club was a citadel as well as fortress to the British (Larkin, 2004:29).

In 1923, the British introduced a new rule which allow a small number of Burmese politicians attend the parliament meeting. This rule also applied to British clubs across the country. They were forced to accept a local member. However, the segregation remained strong. Larkin gave an example where:

... the Burmese official who was appointed acting governor in place of the British governor who was away on sick leave was denied access to the Rangoon clubs (Larkin, 2004:188)

This evidence shows that how strong the segregation was between the British and Burmese. Thus, the fulfilment of the new regulation was merely to obey the rule for its sake not to accommodate the Burmese of their rights.

\section{Burmese Officials in the British Raj}

When the British annexed Burma, they exiled the king and queen of last Burmese dynasty and began to employ a new form of government. Burma became the part of British India or British Raj. In doing so, the British government "... had removed the respected headmen and replaced them with its own bureaucratic counterparts." (Larkin, 2004:67). Thus, many magistrates and other local officials were corrupt because as long as they performed the duty as told by the British, they secured their position the government. They practiced corruption mainly by taking bribery.

\section{Racism of the British towards Burmese}

Orwell believed that racism in the key element of British colonial system. As he became an eyewitness of colonial in Burma where he worked as police officer, he concluded an example of racism practice done by British every day.

Burma was known for the extreme weather in the summer when intolerably hot sun stung one's head like a bee. The British always wore Topi whenever they went out to avoid the sun. However, the Burmese never wore one. Consequently, the British believed that the Burmese were biologically different as they did not need any protection from the sun. This illustration sums up his idea that:

You can only rule over a subject race, especially when you are in a small minority, if you honestly believe yourself to be racially superior, and it helps towards this if you can believe that the subject race is biologically different (Larkin, 2004:160).

The British believed that such practices would differ them from the local natives. They would feel superior as they thought because human needs protection from the heat of the sun whereas the Burmese were only 'savage' to them.

Pagoda as The Center of Religious Identity 
Most of Burmese were Buddhist when the British came to the country. Today, Myanmar is a country that take Buddhist as their national religion. Pagoda is a quintessential for Burmese as an individual as well as for the country. Larkin on her trip to Burma to trace Orwell back years ago comments that:

Pagoda are the center of Burmese spiritual life, and every town and village has one. People visit the pagoda daily or weekly to pay respect to the Buddha relics which are often enshrined there, to meditate, to give alms, or to attend the festivals held on religious holidays (Larkin, 2004:77)

Pagoda is the symbol of Buddhism where Buddhist people practice the religion there. For Burmese people, pagoda has immersed in their hearts as they always put the pagoda as center of everything they do, especially in religious affairs. Thus, pagoda is inseparable from Burmese culture because it plays vital role to Burmese society since hundreds years ago.

They strongly believe in reincarnation and karma. How the karma works is typical where one has to perform duty as a devoted Buddhist and also they must outweigh their sin by doing good deeds. For those who are rich enough, they will donate sum of money to build pagodas. Their sins would also be redeemed by the number of pagoda they build. According to Larkin when she was tracing Orwell back in Burma in early 2000, she found out the practice of the general who donate his money to build pagodas. On a newspaper, she read that a high ranking official, General Khin Nyunt, gave 900,000 kyats (equal to 900 US Dollars) donation for a pagoda (Larkin, 2004:79).

The idea of donating money for pagoda is supposed to be a religious affair to many Buddhist in Burma. They would do so if they have enough money. The practice was also performed by kings of Burma, 'the royal patrons of the Buddhist religion' dated years ago (Larkin, 2004:78). However, Burma was under junta military government for more than two decades. During this time the people were severely suffered as the army led the country nowhere but towards poverty. The army also tortured the people, jail those who oppose the government, and abusing young women (Larkin, 2004:78). Thus, General Khin Nyunt who pretend himself as a good Buddhist try to outweigh his 'sins' by donating the pagoda.

\section{Crisis of Identity suffered by U Po Kyin} 1. The Characterization of U Po Kyin

Kyin is characterized in a way of showing. The author of Burmese Days provides vast details in comments of Kyin actions rather than his own voice. However, some of Kyin's manners and qualities are observed from his conversation with another character such as his wife. Most of the times, the narrator reveals Kyin's thought directly to the readers. Kyin' desires, temperaments and moral natures are observed through the description of the character by the narrator. Therefore, it is noticed that Kyin's ambition remain stable and unchanged throughout the novel.

From the beginning of the novel the readers are presented with the description of Kyin. The narrator begins with "U Po Kyin, Subdivisional Magistrate of Kyauktada, in Upper Burma, was sitting in his veranda" (Orwell, 1934:5). After that, the narrator goes on with the description of the time and situation of the moment Kyin is sitting in his veranda. Kyin's appearance is also narrated in details as seen in:

Unblinking, rather like a great porcelain idol, $U$ Po Kyin gazed out into the fierce sunlight. He was a man of fifty, so fat that for years he had not risen from his chair without help, and yet shapely and even beautiful in his grossness; for the Burmese do not sag and bulge like white men, but grow fat symmetrically, like fruits swelling. His face was vast, yellow and quite unwrinkled, and his eyes were tawny (Orwell, 1934:5). 
That is why, most of Kyin's manners, attitudes and qualities are observed through telling way characterization.

U Po Kyin's admiration of British Empire began when he was a little boy. One day he saw an army of British Empire marching in Mandalay streets. According to history, this was the day when the British finally captured the capital city of Burmese Kingdom. After that, last king and queen of Burma dynasty, Thibaw and Supalayat were exiled to India. Since then, Kyin has been living his life by believing that someday he would acquire the Englishness.

Kyin is considered as a sly man. This can be observed from how he manages to excel in his career. He keeps being promoted not because of his good works but his cunning practices. When he works at the bazaar as a clerk for a rice merchant, he also sometimes steals. The way he gets his job at the government is by bribing with money he has from blackmailing someone.

Then when he was twenty a lucky stroke of blackmail put him in possession of four hundred rupees, and he went at once to Rangoon and bought his way into a Government clerkship (Orwell, 1934:6).

It is when the author narrates that Kyin starts his career in an untrustworthy way. He does not get work because he has the ability to perform the job but he 'buys' the position.

The narrator continues to build a character on Kyin to have devilish thought and ambition. When there is an article on a bilingual patriotic newspaper called "Burmese Patriot", exposing and blaming an English Deputy Commissioner named Macgregor, Kyin seizes the chance to put an Indian-born doctor, Verasvami, to be blamed. He says:

Now, let us go into this affair from the beginning. We are going to make a concerted attack on Dr. Veraswami, who is the Civil Surgeon and Superintendent of the jail. We are going to slander him, destroy his reputation and finally ruin him forever. It will be a delicate operation (Orwell, 1934:11).

He produces an anonymous letter to be sent to Macgregor in order to convince him that it is Dr. Verasvami who writes the article. The narrator successfully delivers the image of Kyin as a corrupt official. Therefore, it is clear that he wants more than denouncing the doctor. His discussion with his wife continues when he mentions what his real intention is. He says that:

It is this. I happen to know that in a month's time the Europeans are going to elect one native member to their Club. They do not want to do it, but they will have orders from the Commissioner, and they will obey. Naturally, they would elect Veraswami, who is the highest native official in the district. But I have disgraced Veraswami. And so----(Orwell, 1934: 143).

The European Club is an elite club where atmosphere of British is reproduced daily by placing bar and bridges card-game in the room. The members of the club are obviously all British and other Europeans. When the regulation to elect a local native member is spread out, many rejections come from most members of Kyauktada's Club. Kyin definitely wants to get the membership as he believes by being the member of the club, his status in the society would be raised.

More complexities in the characterization are added when the narrator creates more intrigues to the story. Kyin's plan of anonymous letters continues but does not necessarily succeed. He, then, creates a false rebellion issue in the town. This can be seen as an effort to destroy the doctor's reputation as Kyin himself said:

This rebellion is the very thing to get rid of him. Of course we shall never prove that he is responsible for it; but what does that matter? All the Europeans will take it for granted that he is mixed up in 
it somehow. That is how their minds work. He will be ruined for life. And his fall is my rise (Orwell, 1934: 140).

This is the time when the doctor receives support no more because his European friend had been ashamed because of the scene in the church. He then shoots himself to death. By this time a final false accusation Kyin throws at Dr. Verasvami results in a catastrophe. The European could no longer see Dr. Verasvami as a doctor with a good reputation anymore. Kyin finally gets the membership of the club though rejections of many European members are still around. He comes to the club rarely. When he comes, he is there mainly for drinking and playing bridge. Most of the times, the rest of the members do not consider his presence at all.

At the end of his career, he keeps being promoted after taking many credits from the riot at Kyautada. He is Deputy Commissioner before he retires. He is also awarded a medal to recognize his service to the British Empire. He is still greedy as before but richer by taking a huge amount of bribery alone. As he is afraid of Karma he would get after making many evildoings through his life, he decides to redeem his sins by making pagodas. Unfortunately, he is dead before he could do so.

\section{Crisis of Identity of $U$ Po Kyin}

The marching of the British soldiers in the street of Mandalay symbolizes the intervention of the colonial in the Burmese culture. The young Kyin as a Burmese does not realize the oppression because the form of oppression is unconscious to Kyin. Ashcroft named this situation as cultural denigration that happens because "the conscious and unconscious oppression of the indigenous personality and culture by a supposedly superior racial or cultural model" (Aschroft, 2002:9). Burmese culture is now denigrated as the British takes control in every aspect of life in Burma. This also means that Kyin's self-image of being Burmese is challenged.
There are some evidences that picture Kyin's childhood who was a fan of British since then. As explained in the characterization of the character, Kyin holds a high position the British Colonial government system in Burma. He is the Subdivisional Magistrate of Kyakutada in the beginning in the novel. He kept being a corrupt official by taking bribe and terrorizing the locals. He then realized that there was a chance to be promoted to high level as states:

Now, at fifty-six, he was a Sub-div isional Magistrate, and he would probably be promoted and made an acting Deputy Commissioner, with Englishmen as his equals and even his subordinates (Orwell, 1934:6).

This shows his burning ambition to take his chance and make his childhood dream comes true. Thus, it is not a surprise when he deploys many kinds of evil plans to clear his career path in order to foster his desire to be like English man.

The desire to attain the status of Englishmen is a sign of Kyin's alienation within his Burmese society. He puts a lot effort to identify his self with an alternative identity because he feels he does not want to belong to Burmese as colonial subject. Ashcroft notes this as the result of displacement. He said:

the possession and practice of 'Englishness', also show clear signs of alienation even within the first generation of settlement, and manifest a tendency to seek an alternative, differentiated identity? (Ashcroft, 2002:9)

Therefore, Kyin chooses the option to pursue his dream to "fight fot the British side" as he has been dreaming of since he was a child.

The picturesque of how Kyin wife explain the concept of hell in Buddhism to Kyin indicates that Kyin's wife is a devoted Burmese Buddhist. This shows Kyin's place in the society that he is a Burmese. However, 
by the intervention of the British into their culture alter their idea of life offered by Buddhism and displaced by the image of the English values (Ashcroft, 2002:9). They may or may not aware of the oppression as Kyin also holds a position of a high ranking official in the British colonial government in Burma. However, this still causes their Buddhism image that crafted in their hearts scattered. They are replaced with the image of being English. They then reproduce the idea of karma in Buddhism into their favor to pursue the English self.

At the beginning of the novel Burmese belief of reincarnation is also mentioned. After the narrator describes how corrupt Kyin is, he then talks about how Kyin would redeem his evil doings in his life.

He would devote his closing years to good works, which would pile up enough merit to outweigh the rest of his life. Probably his good works would take the form of building pagodas. Four pagodas, five, six, seven -the priests would tell him how many-... And he would return to the earth in male human shape - ... (Orwell, 1934:7)

Pagoda is an essential aspect of Burmese religious life in Myanmar until now. Larkin confirms this concept when she visited Burma in early 2000. She says:

Pagoda are the center of Burmese spiritual life, and every town and village has one. People visit the pagoda daily or weekly to pay respect to the Buddha relics which are often enshrined there, to meditate, to give alms, or to attend the festivals held on religious holidays (Larkin, 2004:77).

This shows that Kyin is aware of the result of his action from the beginning. In doing so, he is also prepared for redeeming the sins of his. His act of destroying Dr. Verasvami is not an exception of his nature of being a corrupt official from the beginning. Kyin's acts are similar to the practices of general that Larkin observes. She summarizes:
Like today's generals, U Po Kyin, the corrupt Burmese magistrate in Orwell's Burmese Days, considered himself a good Buddhist. He believed that all the evil he had done in this life - cheating people for money ... He therefore planned to devote the later years of his life to doing good works, to counteract out the bad things he had done and balance the scales of karmic justice. (Larkin, 2004:78)

This idea of the centralistic of Buddhism and the idea of karma are not necessarily to be judged on morality basis but on cultural aspect. It means that how Kyin basically is used to have a strong connection with his self-image as a good Buddhist. However, now, he has to manipulate the idea of being good Buddhist to suit his ambition to acquire Englishness.

Kyin is annoyed with his life even though he is in a better situation compared with most Burmese. He seems not to care about his wrong doings, and he even still craves for more. This is also a characteristic of core intention of Kyin which is not to be grateful. He grows more furiously to obtain his desire. He says that:

I am tired of eating with my fingers and associating only with Burmans -poor, inferior people- and living, as you might say, like to feel like a miserable Township Officer. Money is not enough; I should like to feel that I have risen in world as well. (Orwell, 1934: 142)

It is clear that Kyin is ashamed of being Burmese. He acknowledges that being Burmese associates him with inferiority. Ashcroft comments that "a valid and active sense of self may have been eroded" (Ashcroft, 2002:8). This idea approves that Kyin as a Burmese self is eroded because he feels inferior. He also notices that money is not enough for him because his identity is not necessarily formed with money but culture. That is why when his Burmese culture is eroded, he begins to feel inferior and questions his identity. 
When Kyin expresses his view on his current life, he unconsciously admitted that he is in the part of inferior society. Rutherford believes that one's identity is achieved through the polarities of characteristics. He comments that:

It is within their polarities of white/black, masculine/feminine, hetero/homosexual, where one term is always dominant and the other subordinate, that our identities are formed. (Rutherford, 1990:10)

The desire of being the member of the club does not only strike U Po Kyin but also his rival, Dr. Verasvami. Upon knowing Kyin's plans to destroy his reputation, he also begins to develop a desire of the Club. The doctor believes that the only way to avoid of being accused as a proprietor to the Colonial government is elected to the Club. He then indeed mentions his ambition several times to Flory, his British friend, when they have a conversation. He describes the Club as "a fortress impregnable". He is going to use his membership as a shield against any accusation thrown at him. There are at least three times he mentioned his desire to be the member to Flory in only just one conversation. The situation which Kyin has undergone is interrelated with the reading of Bhabha's mimicry concept. Bhabha postulates that "the desire for a reformed, recognizable Other, as a subject of diference that is almost the same but not quite" (Bhabha, 2004:122). As discussed earlier, the ruling ambition of $U$ Po Kyin is 'to be the same but not quite' grows since he is 'a naked pot-bellied' boy. This drives him to advance his career path by launching his dirty campaign towards his challenger, Dr. Verasvami.

In order to support the idea that the $\mathrm{U}$ Po Kyin is in the state of feeling inferiority, it can be seen through Dr. Verasvami, Kyin's rival, when he is talking to Flory, white man, and he says he knows that Kyin launches evil campaign to destroy his reputation in front of the Europeans. When, Flory tries to calm the doctor down, he says that:
All depends upon one's standing with the Europeans. If my standing iss good, they will not believe it of me; if bad, they will believe it. Prestige iss all. (Orwell, 1934:149)

Corresponding to this statement, Flory delivers no argumentation but agreement. The Europeans who always have the sentiment towards local, as discussed earlier in the context of Rutherford's idea of identity, that locals are always bad and wrong. Those who could gain their respect are only local natives who have good reputation.

U Po Kyin mentions the word of inferiority or things associate to it. It is true that he holds a high ranking official the local can attain to in the British Raj system, but he cannot detach himself from the society that is denigrated. Ashcroft pictures this as "cultural denigration, the conscious and unconscious oppression of the indigenous personality and culture by a supposedly superior racial or cultural model." (Ashcroft, 2002:9) The affirmation of their inferiority status is uttered by another member of the same society, fellow colonized, Dr. Verasvami. He has remarked that "'Hanging together', ass you call it. It iss the secret of your superiority to we Orientals" (Orwell, 1934:147). This statement contains the idea of dependency as well as the acknowledgment of the colonizer power and superiority. In that statement, the doctor needs Flory as a white man to maintain and gain more status in order to elevate their position among the society.

\section{Crisis of Identity Leading to Mimicry of U Po Kyin}

Kyin begins his life as a beggar who later climbs the ladder of success until he has a position of a Sub-divisional magistrate in the British colonial government. This shows that he is placed at the margin of the colonized society. When he holds the position such as a Sub-divisional magistrate he will always pursue a higher position as a Deputy Commissioner. Ashcroft uses 
Edward Said's terms "a process of conscious affiliation proceeding from a desire not only to be accepted but to be adopted and absorbed" (Ashcroft, 2002:4). Ashcroft comments that those who are at the periphery of colonization society are going to unite and abandon their origins. Kyin is undergoing this process since he dreams and decides to work for the British when he was a little boy. He then keeps the intention growing by plotting his way to get the merits of his work.

Kyin's effort to mimic the colonizer, the British, is seen according to Bhabha as "desire of the reformed" (Bhabha, 2004:122). Kyin rejects as well as accepts the idea of being colonized who is placed at the periphery of colonialization. $\mathrm{He}$ and other Burmese are the subjects of colonialization who are excessively abused by the power of the British. However, he is benefited by having the position of a Subdivisional magistrate. This gives him a better opportunity to launch another dream to be like the British socially. Entering the Club is a perfect ambition to him.

\section{Mimicry of U Po Kyin}

The initial moment of the process of mimicry is when U Po Kyin delivers the idea of being the member of the European Club to his wife. After she hears her husband delivers the idea, she begins to imagine what will happen if she is the wife of the member of the Club. She comments that "talking to English ladies in Hindustani about babylinen" would amaze for any women in her community. This amplifies that the motive of being chosen as a member in the club for Kyin's family is not only to get respected by local natives. This also articulates the idea of being the European alike.

Historically, when the British issued a diarchy rule in 1923 , only a small number of the Burmese politicians were allowed to attend the parliament's session. This rule also affects any British Clubs all over the country. Most British bitterly accept the present of Burmese in their clubs. However, many reject the Burmese to come to the Clubs. In Burmese Days, one of typical reason was represented by Ellis. He says:
It's all very well, but I stick to what I said. No natives in this Club! It's constantly giving way over small things like that that we've ruined the Empire. This country's only rotten with sedition because we've been too soft with them. The only possible policy is to treat 'em like dirt they are. This is a critical moment, and we want every bit of prestige we can get. We've got to hang together and say, 'We are the masters and you beggars-" Ellis pressed his small thumb down as though flattening a grub- "you beggars keep your place!' (Orwell, 1934:32)

This can be seen as the evidence on how the diarchy policy that issued by British Raj in Burma is not well accepted in most British societies in Burma as pictured by Orwell in the novel.

Larkin has a rare opportunity to interview a Burmese whose father was a district magistrate during the British colonial government in 1920's in Burma. The Burmese named Htin Aung talked to her that his father is invited to join the local club. He mentions that his father is forced to accept the membership (Larkin, 2011:189). His father does not enjoy the privilege of being the member of the club as he only visits the clubs several times on social duty not leisure time.

On the other hand, this fact is apparently reversed by Orwell as he characterizes Kyin as a magistrate who is willing to blackmail and scheme his way to obtain the membership of the Club. Orwell's intention can be seen as an attempt to provide the space for Kyin to possess power as well as the ability to mimic the British by choice not by force as the policy said.

Kyin is described as a corrupt man since the beginning of the novel. The way he reaches his positon as a Magistrate is not 'innocent' from the start. Thus, he managed to secure his positon as he always employs 
clever tricks such as receives the bribes. He also makes a private taxation system for villagers in order get more money. Those who refute would be terrorized by "gangs of dacoits attacked the village, leading villagers were arrested on false charge, and so forth" (Orwell, 1934:7). These terrors are motorized by Kyin.

In postcolonial discourse, the act of Kyin terrorizing his own fellow (other Burmese) is seen as an attempt to mimic the colonizer. The nature of colonizer, indeed, always includes power relation as the based on every interaction. This can be seen from the bipolarity of superior and inferior represented by the British and Burmese. Kyin rejects his Burmese identity because Burmese is the subject of the British colonialization. This corresponds to Bhabha's concept of mimicry. He says mimicry is "the desire for reform, the recognizable other". In this case, Kyin wants to 'differ' himself from the Other, the subject of colonization.

Kyin does not only blatantly mimic the British but he also realizes that colonization is strongly emphasized on the element of racism. As explained in the earlier part of this study, the British see Burmese as inferior race. For instance, under the ferocious heat of Burma sun, the British have to wear protection for their head as they are not used to such extreme heat. However, Burmese were seen off not wearing any protection. The British conclude that Burmese have thick skull. The fact that the British differ themselves biologically from Burmese established racist relation because they notice Burmese are 'savage' and less human as they had no problem with the heat.

Another event amplifies Kyin's effort to be European like. The doctor receives support no more from Flory as Flory has committed suicide. Kyin finally launches his final accusation to obtain his objective to get membership of the club. Dr. Verasvami indeed is destroyed. The Europeans think that he is a scoundrel even though they have no specific reason why they should believe so. The doctor also has been labelled as the "shok de"; a Burmese phrase, whose meaning equals to untrustworthy no to be exact. When a native is labeled by this, it means "there is an end of him" (Orwell, 1934:283). Unlike the doctor, Kyin is profited otherwise. This shows that Kyin successfully differs himself from Dr. Verasvami. The doctor symbolizes the local society while Kyin is now left off to be European like because of the membership.

\section{The Result of Mimicry}

The result of mimicry is ambivalence. Mimicry emphasizes its process rather than the result. The result of mimicry will not be able to produce new characteristics. In the postcolonial discourse, mimicry will affect the local natives because they will transform into the British described as 'almost the same but not quite'. Those who try to mimic the British will not get the same status as them. Kyin is trapped in the illusion he has been dreaming about. In the beginning of the novel, Kyin is described as a Sub-divisional magistrate, a high ranking official for a local people (Orwell, 1934:5). His jurisdiction includes some villages in the discrict of Kyauktada. To him, his position offered power and authority among his people.

This is true since he arranges private taxation scheme to benefit him himself while he also receives bribes from both sides but he solves the dispute honestly. Because he solves any disputes fairly, it profits him with respect as a loyal and skilled official to the British. However, the British will not care about his corrupt practice for Kyin was one of the British officials. Kyin is aware of this that he keeps continuing his corrupt practices since he believes the British would not believe the accusation thrown against his own men (Orwell, 1934:7). He will pile up dozen witnesses if any accusation or trial of his practices. He will always get away with it.

Macaulay's example of a group translator in India provides clear picture of how the ambivalence of mimicry occurs. He comments on class structure in India under the British colonialization. They are the 
colonizer, the British, mimic man, and millions whom the British govern, the common people (Bhabha, 1994:87). What he means by mimic man is a group of Indian who receives colonial education to be translators. The translator group is no longer included in the group with millions others but they form a new social class. However, having received the colonial education job as translators, they remain powerless. Their status as colonial subject is not lifted altogether.

In this case, Kyin is considered in the group of mimic man in India. His position offers him a lot of privileges as a Subdivisional magistrate. The British will not look up upon him neither as a respected Burmese nor as a noble man since the British was understand of the nature of Kyin very well. He will remain as a colonial subject. According to the history, when the British annex Burma, they replace truthful of head villagers with a handful of corrupt Burmese officials (Larkin, 2011:67). They believe corrupt Burmese officials are easy to be controlled as they let them to continue terrorizing villagers instead of protecting them. They are also trapped in the ambivalence of mimicry discourse because Kyin is 'translator' whose power is a little compare to the British officials.

Kyin's membership of the Club does not change how the British members of the Club judge Burmese people. Although, naturally, they will elect Dr. Verasvami, they are thankful when they finally choose Kyin instead. Their attitude is pictured in:

In the end the other Europeans came to be rather glad that they had elected him, for he was bearable addition to the Club. He did not come too often, was ingratiating in his manner, stood drinks freely, and developed almost at once into a brilliant bridge-player. (Orwell, 1934:285)

They are glad because Kyin is almost unnoticed to them because he does not come too often. So, his presence in the Club is not considered as important. On the other hand, this symbolizes that Kyin is successfully mimic the British because he is now able to socialize with the rest of the member by acquiring a skill to be a brilliant bridgeplayer. His significance to the Club is only his privilege of entering the Club. He does not represent any Burmese politically and he has no power in Club to express his opinion.

When Kyin has achieved everything more than he has been dreaming about, he fails to redeem his sins by building pagodas. This is an ambivalence result of mimicry because he still considers himself as a devoted Burmese. It is the moment for him to atone for his sins as stated in "U Po Kyin had done all that mortal man could do. It was time now to be making ready for the next world - in short, to begin building pagodas." (Orwell, 1934:286). In the earlier part of this study, when Kyin begins to blackmail and scheme Dr. Verasvami, he was warned that one day he has to redeem his evildoings by building pagodas. Unfortunately, it is not long after he is granted an award by the British governor, he is stricken by apoplexy. He is dead several days afterwards.

Pagodas are the center of Burmese people as devoted Buddhist. The idea of Kyin remembers his atonement of building pagoda show that he is still attached to Burmese culture. Like Macaulay's example, the translators group in India who he considers them to be powerless because of selective knowledge they acquire from the British, Kyin is also powerless. He could not fulfill his duty as a Buddhist. This is also a sign of difference and the lack of authority for Kyin. He is different than the British although he has the highest position for the local natives can get in the government of British colonial. He still has to perform his duty as a Burmese and Buddhist. On the other hand, Kyin can be seen as an example for other Burmese. Kyin is a signification for Burmese because they can reach such a high position in the British colonial government.

\section{Conclusion}

U Po Kyin is characterized a corrupt official. He is also portrayed as an evil 
character as he always finds a way to denigrate his rival in order to get the membership of the Club. Kyin nurtures his admiration towards the British since he was little. This shows how Kyin begins to content with the idea of fighting for the British instead of Burmese. Although, this happens when he is child, the idea does not disappear but grow. This happens because Kyin selfimage of being burmese is denigrated by the presence of the British. When he finally holds a quite high ranking local official as a Sub-divisional magistrate with several villages under him jurisdiction, his ambition to fight for the British transforms into entering 'the Club'.

The Club represents a new signifier for Kyin's ambition to fight for the British. Now, his ambition to fight for the British is replaced but the idea is still the same. The Club also represents Kyin's condition as he suffers from crisis of identity. He realizes the importance of the Club. In order to elevate his social status among the local natives, the Club offers him with a lot of privileges. He believes those privileges will erase his inferiority status in front of the British.

Even though Kyin is warned by his wife that he has to atone for sins by building pagodas, Kyin makes his way to get the membership. His blackmails and scheme successfully destroy the good image of Dr. Verasvami. His presence at the Club is occasional. When he is at the Club, he has found a way to socialize with the British by being a good bridge-player. Other impact of his presence is almost none because he does not represent any Burmese to voice his opinion in the Club. He takes the Club a place to spend some leisure time. This again corresponds to the idea that mimicry is not a representation.

The result of mimicry is ambivalence. His failure of building pagodas to gain merits to atone his evildoings signifies that he still lacks of authority. He is indeed promoted even further so that he achieves a medal of honor from the British Governor. He is also wealthier than ever as he keeps doing his corrupt practices by taking bribes. However, these all do not provide him enough power to perform his duty as a devoted Buddhist and Burmese. $\mathrm{He}$ is still a postcolonial subject because he cannot fully attach himself from the Buddhist and Burmese tradition. On the other hand, the British also consider him just the same like other Burmese as the colonial subject.

\section{References}

Abrams, M.H. and Geoffrey G. Harpham. Glossary of Literary Terms, $9^{\text {th }}$ Edition. Boston: Wadsworth Cengage Learning, 2009.

Aschroft, Bill and Gareth Griffiths and Hellen Tiffin. The Empire Writes Back. New York: Routledge, 2002.

Barry, Peter. Beginning Theory: An Introduction to Literary and Cultural Theory, $3^{\text {rd }}$ Edition. Manchester and New York: Manchester University Press, 2009.

Bhabha, Homi K. The Location of Culture. Classics ed. London: Routledge, 2004.

Gopinath, Praseeda. "An Orphaned Manliness: the Pukka Sahib and the End of Empire in Passage to India and Nurmese Days". Studies in the Novel, Vol. 41, No. 2 (summer 2009), pp. 201-223. The Johns Hopkins University Press. (http://www.jstor.org/stable/2402714 8). August 5, 2016.

Holman, C Hugh and William Harmon. A Handbook to Literature, $5^{\text {th }}$ Edition. New York: Macmillan Publishing Company, 1986

Guerin, Wilfred L. Earle Labor, Lee Morgan, and John R. Willingham. A Handbook of Critical Approaches to Literature, $6^{\text {th }}$ Edition. Oxford and New York: Oxford University Press, 2011. 
Larkin, Emma. Finding Orwell in Burma. London and New York: Penguin Books, 2006.

Lee, Robert A. "Symbol and Structure in Burmese Days : A Revaluation". Texas Studies in Literature and Language, Vol. 11, No. 1 (Spring 1969), pp. 819-835 University of Texas Press. (www.jstor. org/stable/40754032). August 5, 2016.

Loomba, Ania. Colonialism/Postcolonialism. London and New York: Routledge, 2005.

Orwell, George. Burmese Days. New York: Harcourt, 1934.

Orwell, George. Collected Essay. London: Mercury Books, 1961.

Phyo Tha, Kyaw. Orwell's 'Burmese Days' Wins Govt Literary Award. The Irrawaddy. November 19, 2013. (http://www.irrawaddy.com/burma/or wells-burmese-days-wins-govt-literaryaward.html). August 5, 2016.

Poznar, Walter. "Orwell and Little Brother". College Literature, Vol. 12, No. 3 (Fall, 1985), pp. 258-265. The Johns Hopkins University Press. (http://www.jstor.org/ stable/25111672). August 3, 2016.

Rai, Alok. "Colonial Fictions: Orwell's 'Burmese Days'". Economic and Political Weekly, Vol. 18, No. 5 (Jan. 29, 1983), pp. PE47-PE52. Economic and Political Weekly. www.jstor.org/stable/437180). August 5, 2016.

Roberts, Edgar V. and Henry E. Jacobs. Fiction: An Introduction to Reading and Writing. New Jersey: Prentice-Hall, Inc., 1987.

Rutherford, Jonathan. Identity: Community, Culture, Difference. London: Lawrence \& Wishart Limited, 1990.

"Why I write". George Orwell. 1946

(http://web.calstatela.edu/faculty/jgarret/3 08/readings-4.pdf). June 3, 2015.
Wiharyanto, Kardiyat A. Asia Tenggara Zaman Pranasionalisme. Yogyakarta: Universitas Sanata Dharma, 2005. 